\title{
Supercritical Carbon Dioxide Extraction of Polyphenols from Pomegranate (Punica granatum L.) Leaves: Chemical Composition, Economic Evaluation and Chemometric Approach
}

\author{
Rodrigo N. Cavalcanti ${ }^{1}$, Helmut J. Navarro-Díaz ${ }^{1}$, Diego T. Santos ${ }^{1}$, Mauricio A. Rostagno ${ }^{1} \&$ M. Angela A. \\ Meireles ${ }^{1}$ \\ ${ }^{1}$ LASEFI/DEA/FEA (School of Food Engineering)/UNICAMP (University of Campinas), Brazil \\ Correspondence: M. Angela A. Meireles, LASEFI/DEA/FEA (School of Food Engineering)/UNICAMP \\ (University of Campinas), Rua Monteiro Lobato, 80, 13083-862, Campinas, São Paulo, Brazil. Tel: \\ 55-19-3521-4033. E-mail: meireles@fea.unicamp.br
}

Received: June 18, 2012 Accepted: July 4, 2012 Online Published: July 27, 2012

doi:10.5539/jfr.v1n3p282 URL: http://dx.doi.org/10.5539/jfr.v1n3p282

\begin{abstract}
The increasing demand for high-quality products and economically and environmentally friendly technologies, as well as restrictive legislative actions, has stimulated scientific research on the extraction, purification and identification of bioactive compounds from natural sources. Pomegranate (Punica granatum L.) is commonly used in traditional medicine due to its pharmacological properties, such as its anti-inflammatory, antihepatotoxicity, anti-lipoperoxidation, antidiabetic, anti-cancer and antimicrobial activities. The use of industrial residues as sources of bioactive compounds has emerged as an economically viable solution to the problem of solid waste treatment. In this context, this work aimed to evaluate the $\mathrm{SC}-\mathrm{CO}_{2}$ extraction of polyphenols from pomegranate leaves, evaluating the influence of temperature $\left(40\right.$ and $\left.50^{\circ} \mathrm{C}\right)$ and pressure (10-30 MPa) on extraction yield (EY), total phenolic content (TPC), antioxidant activity (AA) and the cost of manufacturing (COM) of the extracts. Principal component analysis (PCA) was used to reduce the dimensionality of multivariate data, making the visualization more straightforward and manageable. A high EY and TPC and low COM were obtained at the most effective operational conditions of $50^{\circ} \mathrm{C}$ and $30 \mathrm{MPa}$. The lack of correlation between EY-AA and TPC-AA indicated the coextraction of non-phenolic compounds. This assumption was corroborated by GC-MS analysis, which showed high levels of eicosanol, squalene, linoleic acid and tocols. Even though SC- $\mathrm{CO}_{2}$ extraction resulted in a high TPC (257-389 mg. $\left.\mathrm{g}^{-1}\right)$ compared to the literature data, the low EY (0.21-0.67 \%) and non-phenolic presence suggest that $\mathrm{SC}_{-} \mathrm{CO}_{2}$ extraction may be a good purification pretreatment for the removal of non-polyphenolic compounds prior to further polyphenol extraction.
\end{abstract}

Keywords: antioxidant activity, phenolic compounds, Punica granatum L., supercritical fluid extraction, pomegranate, cost of manufacturing, principal component analysis

\section{Introduction}

Pomegranate (Punica granatum L.), a shrub native to the Mediterranean region with a vast ethno-medical history, is extensively used in traditional medicine due to its therapeutic properties (Kaneria, Bapodara, \& Chanda, 2012). An increasing number of studies report the potential beneficial effects of pomegranate on human health (Johanningsmeier \& Harris, 2011; Viuda-Martos, Fernández-Lóaez, \& Pérez-álvarez, 2010). The major pharmacological functions attributed to pomegranate extracts include anti-LDL-cholesterol (Anoosh, Mojtaba, \& Fatemeh, 2010), anti-fibrotic (Toklu et al., 2007; Toklu et al., 2009), anti-inflammatory (Lansky \& Newman, 2007; Lee, Chen, Liang, \& Wang, 2010), antihepatotoxicity (Kaur, Jabbar, Athar, \& Alam, 2006), antilipoperoxidation (Reddy, Gupta, Jacob, Khan, \& Ferreira, 2007), antidiabetic (Das \& Barman, 2012; Huang et al., 2005; Sharma \& Arya, 2011), anti-obesity (Al-Muammar \& Khan, 2012; Lei et al., 2007), anti-cancer (Adhami \& Mukhtar, 2006; Khan, Afaq, Kweon, Kim, \& Mukhtar, 2007; Khan \& Mukhtar, 2007; Lansky \& Newman, 2007), anti-viral (Su, Sangster, \& D'Souza, 2010; 2011), anti-bacterial (Nair \& Chanda, 2005), and anti-fungal activities (Endo, Garcia Cortez, Ueda-Nakamura, Nakamura, \& Dias Filho, 2010; Johann et al., 2008). In this context, the pomegranate leaf stands out as a polyphenol-rich source, exhibiting high levels of flavonoids and tannins, such as punicalin, pedunculagan, gallagic acid, ellagic acid, and its esters of glucose (Kaneria et al., 2012). These compounds have been extensively studied due to their antioxidant, 
anti-inflammatory, and anti-cancer properties (Al-Muammar \& Khan, 2012).

The most commonly used conventional techniques for the extraction of phenolic compounds are soaking, stirring, maceration, and Soxhlet, often using aqueous methanol or ethanol as a solvent (Aguilera-Carbo, Augur, Prado-Barragan, Aguilar, \& Favela-Torres, 2008; Ignat, Volf, \& Popa, 2011). Although these conventional extraction techniques are already well-established, their high energy costs, environmental effects, toxicity, and generation and recovery of large amounts of solvent waste have stimulated the study of alternative methods to overcome these drawbacks (Albuquerque \& Meireles, 2012). Supercritical fluid extraction (SFE) is an interesting alternative for the extraction of natural thermosensitive bioactive compounds that does not generate toxic residues due to its high selectivity, high extraction rate, and low critical point (Brunner, 2005; Herrero, Cifuentes, \& Ibañez, 2006; Herrero, Mendiola, Cifuentes, \& Ibáñez, 2010; Mchugh \& Krukonis, 1994; Pereira \& Meireles, 2010). Several reports describe successful applications of SFE of phenolic compounds from different samples (Casas et al., 2010; Rios \& Gutiérrez-Rosales, 2010; Rostagno, Araújo, \& Sandi, 2002). Recent works have studied alternative methods for obtaining polyphenols from pomegranate ( $\mathrm{Liu}, \mathrm{Xu}, \mathrm{Hao}, \& \mathrm{Gao}, 2009$; Rababah, Banat, Rababah, Ereifej, \& Yang, 2010; Çam \& Hişil, 2010). However, the SFE of phenolics from pomegranate leaves has not yet been reported. In addition, there is a lack of research focused on extraction optimization, particularly with respect to economical and environmental aspects. Thus, the aim of this work was to study the use of $\mathrm{SC}-\mathrm{CO}_{2}$ in the extraction of phenolic compounds from pomegranate leaves, evaluating the extract's chemical composition and the manufacturing cost of the process using principal component analysis as a chemometric method for the reduction and correlation of variables.

\section{Material and Methods}

\subsection{Raw Material and Sample Preparation}

Pomegranate leaves (Punica granatum) were harvested by hand from a plantation located in Lorena, Brazil. The samples were dried in a room at $18^{\circ} \mathrm{C}$ and $25 \%$ humidity for $48 \mathrm{~h}$ until $9.2 \%$ moisture was reached, as determined by the xylol distillation method (Jacobs, 1973). The samples were then comminuted in a knife mill (Tecnal, model TE-631, Piracicaba, Brazil). Particle size analysis was performed using a vibratory sieve system (Model N1868, Bertel, Caieiras, Brazil) using sieves ranging from 16 to 80 mesh (Model ASTME-11, W.S. Tyler, Wheeling, WV, USA). Particles of 24-48 mesh were selected for the SFE assays. The samples were packaged in polyethylene bags and stored in a domestic freezer (Metalfrio, DA420, São Paulo, Brazil) at $-4^{\circ} \mathrm{C}$ until experimentation.

\subsection{Chemical Reagents}

All of the chemicals used to prepare the reagent solutions were of analytical reagent grade. Dry carbon dioxide, 99.9\% purity (Gama, Campinas, Brazil), was used in all experiments. Ethanol (99.5\%) and anhydrous sodium carbonate (99.5\%) were obtained from Ecibra (Santo Amaro, Brazil). Chloroform (99.4\%) and ethyl acetate (99.5\%) were purchased from Merck (Darmstadt, Germany). Tween 40 (99\%), linoleic acid (99\%), and gallic acid $(98 \%)$ were obtained from Sigma-Aldrich (St Louis, MO, USA). $\beta$-Carotene was purchased from Fluka $(>97 \%)$ (Buchs, PA, USA). Folin-Ciocalteu reagent was obtained from Dinâmica (Diadema, Brazil).

\subsection{Supercritical Fluid Extraction Procedure}

All experiments were performed in a Spe-ed SFE unit (Applied Separations, Allentown, USA) using a $6.57 \mathrm{~mL}$ extraction cell. Approximately $20.0 \mathrm{~g}$ of dried and milled pomegranate leaves was loaded into the extraction column, and the remaining volume was filled with glass beads. A factorial experimental design using two temperatures $\left(40\right.$ and $\left.50^{\circ} \mathrm{C}\right)$ and four pressures $(10,15,20$, and $30 \mathrm{MPa})$ was applied. The experiments were performed at a constant $\mathrm{CO}_{2}$ flow rate $\left(0.84 \times 10^{-4} \mathrm{~kg} . \mathrm{s}^{-1}\right)$, apparent bed density of the feed into the extraction column $\left(448 \mathrm{~kg} \cdot \mathrm{m}^{-3}\right)$ and solvent-to-feed mass ratio $(\mathrm{S} / \mathrm{F}=30)$. All of the SFE assays were performed in duplicate.

\subsection{Total Phenolic Content}

The total concentration of phenolic compounds in the supercritical extracts was determined by the Folin-Ciocalteu reagent (FCR) method (Singleton, Orthofer, \& Lamuela-Raventós, 1998). The extracts were dissolved in ethanol and then diluted with distilled water until a concentration of $0.075 \mathrm{mg} / \mathrm{mL}$ was achieved; the ethanol volume did not exceed $10 \%$ of the final solution. Next, $2 \mathrm{~mL}$ of the sample solutions were placed into test tubes and mixed with $10 \mathrm{~mL}$ of a 1:10 aqueous dilution of FCR and then $8 \mathrm{~mL}$ of an anhydrous sodium carbonate solution $(75 \mathrm{mg} / \mathrm{mL})$. All reactions were kept in semidarkness for $5 \mathrm{~min}$ in a water bath $\left(40{ }^{\circ} \mathrm{C}\right)$. The absorbance was then recorded $(760 \mathrm{~nm}$ ) with a UV-Vis spectrophotometer (Hitachi, model U-3010, Tokyo, Japan). The TPC in the extracts was expressed as gallic acid equivalents (GAE), using the gallic acid standard 
curve $\left(5-50 \mu \mathrm{g} \cdot \mathrm{mL}^{-1}\right)$.

\subsection{Antioxidant Activity}

Antioxidant activity was determined by the coupled oxidation reaction of $\beta$-carotene and linoleic acid (Marco, 1968; Miller, 1971). For the emulsion preparation, $1 \mathrm{mg}$ of $\beta$-carotene was diluted in $10 \mathrm{~mL}$ of chloroform; $1 \mathrm{~mL}$ of this solution was then added to a round-bottomed flask containing $20 \mathrm{mg}$ of linoleic acid and $200 \mathrm{mg}$ of Tween 40 . Chloroform was removed using a rotary evaporator with a vacuum controller $\left(40^{\circ} \mathrm{C}, 1.2 \times 10^{-2} \mathrm{MPa}\right)$; next, $50 \mathrm{~mL}$ of oxygenated distilled water was slowly added to the flask with stirring to form an emulsion. The reaction was then performed by adding $5 \mathrm{~mL}$ of the emulsion to a series of test tubes containing $0.2 \mathrm{~mL}$ of the ethanolic antioxidant solution $(0.075 \mathrm{mg} / \mathrm{mL})$. The tubes were vortexed and the absorbance at $470 \mathrm{~nm}$ was recorded after $60 \mathrm{~min}$ at $40^{\circ} \mathrm{C}$. All determinations were made in triplicate. The antioxidant activity was calculated as the percent inhibition of oxidation versus the control sample without any antioxidant solution added using Equation 1 (Burda \& Oleszek, 2001):

$$
A A=\left[1-\frac{\left(A b s_{s}^{0}-A b s_{s}^{t}\right)}{\left(A b s_{c}^{0}-A b s_{c}^{t}\right)}\right] \times 100
$$

where $A A$ is the antioxidant activity expressed in percentage; $A b s_{s}{ }^{0}$ and $A b s_{c}{ }^{0}$ are the sample and control absorbances, respectively, at the beginning of the reaction; and $A b s_{s}{ }^{t}$ and $A b s_{c}{ }^{t}$ are the sample and control absorbances, respectively, at reaction time of $60 \mathrm{~min}$.

\subsection{Process Simulation, Scale-up and Economic Evaluation}

The Association for the Advancement of Cost Engineering International classifies cost of manufacturing (COM) estimations into five classes (1-5) according to the degree of accuracy between the estimated and real COM. The class 5 estimation corresponds to the lowest level of project definition, whereas the class 1 estimation has the most accurate results (Albuquerque \& Meireles, 2012; Turton, Bailie, Whiting, \& Shaeiwitz, 2003). The SFE process simulation and economic evaluation were performed using the software SuperPro Designer ${ }^{\mathbb{B}}$ version 6.0 (Prado, Assis, Maróstica-Júnior, \& Meireles, 2010), which was chosen because of its high level of accuracy (class 2-3) (Turton et al., 2003). The process simulation considered an industrial scale unit composed of two extraction columns, one flash tank, one $\mathrm{CO}_{2}$ reservoir, one $\mathrm{CO}_{2}$ pump, one heat exchanger, and one $\mathrm{CO}_{2}$ compressor for recycling $\mathrm{CO}_{2}$, as shown in Figure 1. The SFE unit was simulated as operating in a semi-continuous mode for 330 day.year ${ }^{-1}, 24$ h.day $^{-1}$, totaling 7920 h.year ${ }^{-1}$. The scale-up procedure assumed that the apparent bed density, extraction yield, and extraction time of the industrial process would be the same as those in the laboratory-scale procedure if the solvent-to-feed mass ratio $(\mathrm{S} / \mathrm{F})$ is constant. These assumptions have been corroborated by several previous works (Albuquerque \& Meireles, 2012; Pereira \& Meireles, 2010; Rosa \& Meireles, 2005; Santos, Veggi, \& Meireles, 2010). The feed mass was scaled-up as estimated according to the apparent bed density and extraction column volume. The mass of the solvent was determined by the S/F ratio.

The COM was estimated as a weighed sum of five main costs: fixed cost of investment (FCI), cost of operational labor (COL), cost of utilities (CUT), cost of waste treatment (CWT), and cost of raw material (CRM) (Turton et al., 2003):

$$
C O M=0.304 F C I+2.73 C O L+1.23(C U T+C W T+C R M)
$$

The FCI involves equipment expenses. The process simulation was conducted considering three extraction columns of $0.1,0.4$, and $1.0 \mathrm{~m}^{3}$ at costs of US\$ 300,000 , US\$ 450,000 , and US\$ 850,000 , respectively. An annual depreciation rate of $10 \%$ was considered. The CUT estimation was based on the energy involved in the solvent cycle: steam (US\$ 4.20/ton) used in the flash tank and heat exchanger, cold water (US\$ 0.19/ton) used in the condenser, and electricity (US\$ $0.092 / \mathrm{kWh}$ ). The COL was estimated using the number of operators needed per shift, depending on the extraction column capacity of the plant $\left(1,2\right.$, and 3 operators for $0.1,0.4$, and $1.0 \mathrm{~m}^{3}$, respectively). Labor charges and labor not directly associated with production were estimated by the simulator. The CRM consisted of the cost of the plant matrix and $\mathrm{CO}_{2}$ loss. The plant matrix cost was estimated as zero as the pomegranate leaf is considered a non-commercial residue. The $\mathrm{CO}_{2}$ loss is mainly due to depressurization at the end of each extraction cycle and was assumed to be $1 \%$ (Perrut, 2007). The CWT was neglected because the solid waste is an organic residue that can be incorporated into the soil and the $\mathrm{CO}_{2}$ lost during the process did not need any treatment because it was considered not harmful in small quantities. 


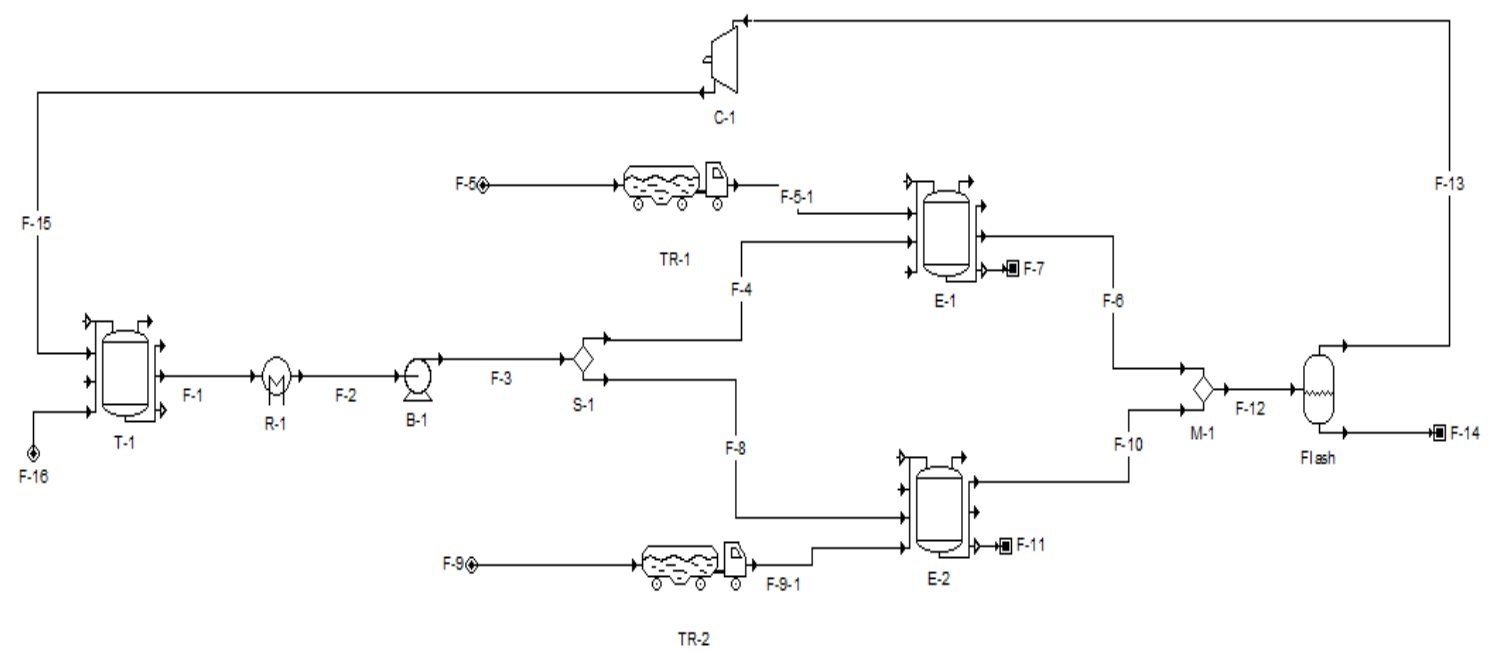

Streams

$$
\begin{aligned}
& \text { F-16 - } \mathrm{CO}_{2} \text { input } \\
& \text { F-13/F-15 }-\mathrm{CO}_{2} \text { recycling } \\
& \text { F-5/F-5-1/F-9/F-9-1 - Raw material feeding } \\
& \text { F-1/F-2/F-3/F-4/F-8 }-\mathrm{CO}_{2} \text { feeding } \\
& \text { F-6/F-10/F-12 - Extract }+\mathrm{CO}_{2} \\
& \text { F-7/F-11 - Solid waste }+\mathrm{CO}_{2} \text { loss } \\
& \text { F-14 - Extract collection }
\end{aligned}
$$

\section{Equipments}

B-1 - $\mathrm{CO}_{2}$ pump

C-1 - Compressor

E-1/E-2 - Extraction column

R-1 - $\mathrm{CO}_{2}$ cooler

$\mathrm{T}-1-\mathrm{CO}_{2}$ reservoir

Flash - Flash tank

S-1 - Stream separator

M-1 - Stream mixer

TR-1/TR-2 - Raw material pre-processing

Figure 1. Scheme of the SFE process simulated by the SuperPro Designer ${ }^{\circledR}$ version 6.0 operating in semi-continuous mode with two extraction columns used for economical evaluation

\subsection{Gas Chromatography-mass Spectrometry}

The samples were prepared by dissolving $10 \mathrm{mg}$ of the extracts in $1.0 \mathrm{~mL}$ of ethyl acetate. The analyses of the extracts were performed on a Hewlett-Packard 5970 GC quadrupole system. The samples were separated by a capillary HP-5MS column $(30 \mathrm{~m} \times 0.25 \mathrm{~mm} ; 0.25 \mu \mathrm{m}$ film thickness; Agilent Technologies, Palo Alto, USA). The column temperature was increased from $60^{\circ} \mathrm{C}$ to $240{ }^{\circ} \mathrm{C}\left(3^{\circ} \mathrm{C} \cdot \mathrm{min}^{-1}\right)$ and held at this temperature for $20 \mathrm{~min}$ Helium was used as the carrier gas with a flow rate of $1.1 \mathrm{~mL} \cdot \mathrm{min}^{-1}$. The injection volume was $1 \mu \mathrm{L}$ in split mode (1:20). The interface temperature was held at $300{ }^{\circ} \mathrm{C}$. Mass spectra were obtained from $\mathrm{m} / \mathrm{z} 40$ to 650 at a rate of $0.5 \mathrm{scans} / \mathrm{s}$. The electron impact ionization energy was $70 \mathrm{eV}$. The databases used for the identification of the sample components were WILEY275 and NIST05. Spectrum interpretation was performed by the Automated Mass Spectral Decovolution Mass and Identification System (AMDIS).

\subsection{Statistical Analysis}

The results were statistically analyzed by analysis of variance (ANOVA). Statistical significance was accepted at a level of 5\%. Pearson's correlation analysis was used to determine correlation coefficients and their statistical significance. Multivariate statistical analysis was performed by principal component analysis (PCA) using the correlation matrix containing the autoscaled data (Souza et al., 2011). A graphical statistical analysis biplot was created to better visualize the relationship between the variables. Both ANOVA and PCA were performed with the software XLSTAT for Windows, version 2011 (Addinsoft, Paris, France).

\section{Results and Discussion}

\subsection{Extraction Yield Isotherms}

As can be seen in Figure 2-A, the extraction yield of the pomegranate leaves increased with pressure in both 
isotherms. The pressure effect on solubility is directly linked to fluid density. Increasing the extraction pressure causes an increase in the fluid density, which represents an increase in the solvent power of the supercritical fluid, thus improving its capability to dissolve the soluble material present in the matrix. The extraction yields obtained in our study were very low $(0.21-0.67 \%, \mathrm{w} / \mathrm{w})$ compared to conventional extraction techniques (Kaneria \& Chanda, 2012; Zhang, Yang, Zhang, Wang, \& Zhang, 2011). Kaneria and Chanda (2012) studied Soxhlet extractions using different solvents and achieved the following extraction yields $(\%$, w/w): water (28.76) > acetone (6.76) > petroleum ether (3.45) > ethyl acetate (2.03) > toluene (1.12). Zhang et al. (2011) obtained even higher extraction yields $(31.53 \pm 0.78)$ using maceration with $70 \%$ ethanol.

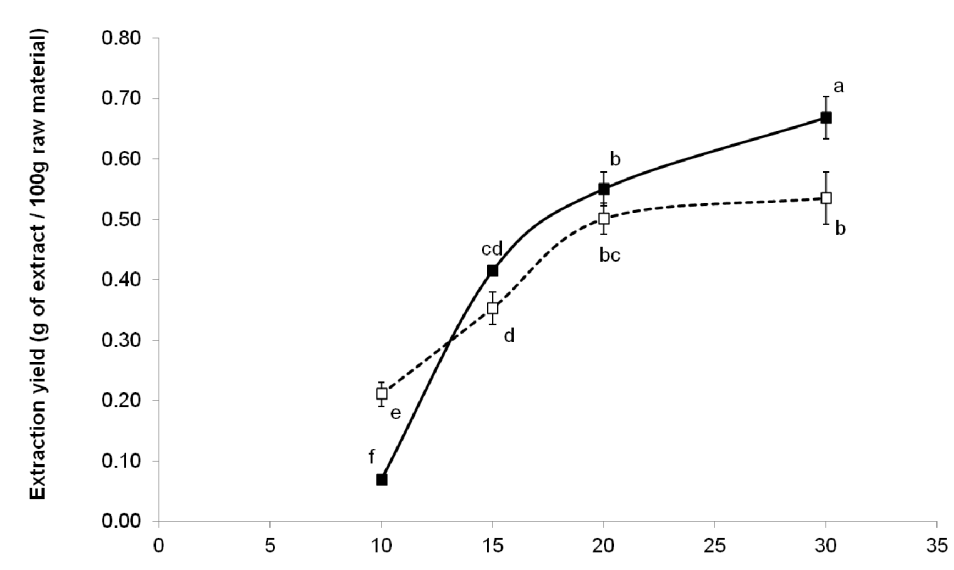

(A)

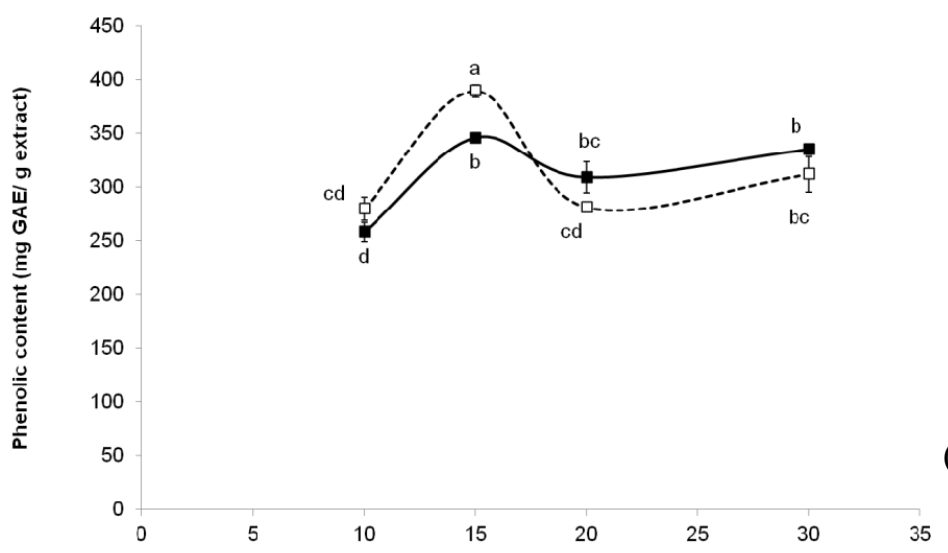

(B)

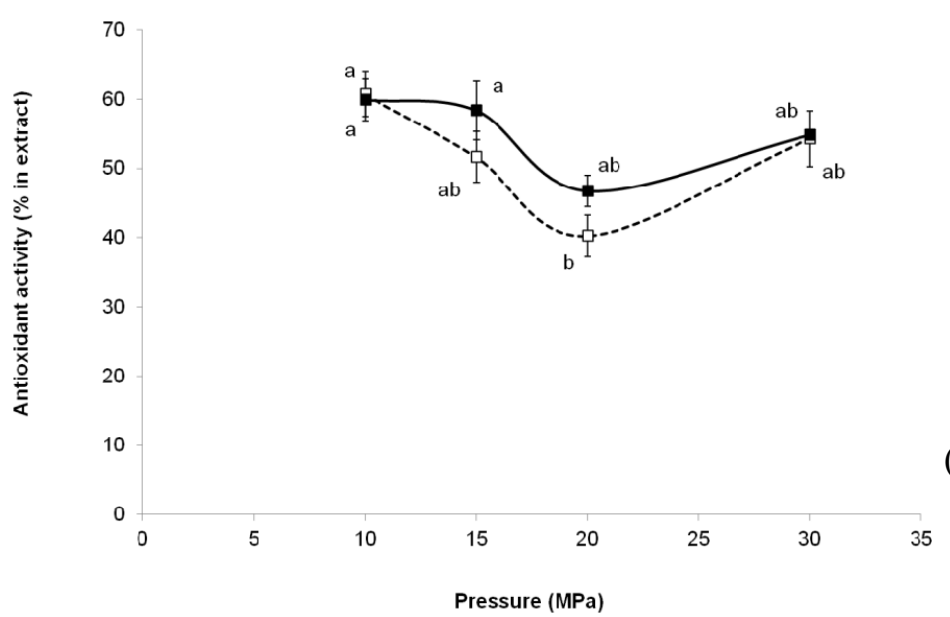

Figure 2. Extraction yield (A), phenolic content (B) and antioxidant activity (C) of pomegranate leaf supercritical extracts at $40^{\circ} \mathrm{C}(\square)$ and $50^{\circ} \mathrm{C}($ 
A density- and volatility-dependent retrogradation in the solubility behavior is observed at the crossover point at approximately $13 \mathrm{MPa}$ in the extraction yield isotherms. An isobaric temperature increase causes a supercritical solvent's density to decrease, implying that the solubility decrease is attributable to the density effect (Mchugh \& Krukonis, 1994; Taylor, 1996). Moreover, the same increase in temperature increases the vapor pressure of the solute, which increases the solubility caused by the volatility effect. Thus, at pressures lower than the crossover point (13 MPa in this case), the density effect is more pronounced than the volatility, facilitating the increase in solubility by either an isobaric decrease in temperature or the corresponding increases in density. However, beyond the crossover pressure, the effect of volatility is more pronounced than the effect of density, resulting in an increase in solubility with an increase in temperature. The crossover pressures are distinct for different solutes (Mchugh \& Krukonis, 1994; Taylor, 1996). Such information could be useful in extract purification/fractionation processes. Furthermore, knowledge of the influence of pressure and temperature conditions on extraction yield is important when an economic evaluation of the industrial process is desired. However, the selection of the optimal conditions should also consider the extract's phytochemical composition and biological activities.

\subsection{Phenolic Content}

The TPC of the pomegranate leaf extracts is expressed as gallic acid equivalents milligrams per gram of the dried extract (GAE mg. $\mathrm{g}^{-1}$ ) (Figure 2B). As with extraction yield, a crossover pressure in the isotherms can be seen at approximately $17 \mathrm{MPa}$. This figure illustrates increasing the extraction pressure from 10 to $15 \mathrm{MPa}$ significantly increased the TPC of the extracts in both isotherms (279.6-389.3 and 257.8-345.7 GAE mg. $\mathrm{g}^{-1}$ for $40^{\circ} \mathrm{C}$ and $50^{\circ} \mathrm{C}$, respectively); these results were significantly different from each other $(\mathrm{p}<0.05)$. However, unlike extraction yield, further increases in pressure had a detrimental effect on TPC, independent of temperature. Temperature had little effect on the TPC of the samples except at a pressure of $15 \mathrm{MPa}$, where the highest concentration of polyphenols was found in the extracts. The phenolic content of the extracts obtained in this work were similar or even higher than those obtained in other works (Garima \& Akoh, 2009; Tehranifar, Selahvarzi, Kharrazi, \& Bakhsh, 2011; Zhang, Gao, Zhang, Liu, \& Yu, 2010; Zhang et al., 2011). Tehranifar et al (2011) studied the extraction of polyphenols by maceration with water or methanol, obtaining a TPC of 98.6 and 133.3 GAE mg. $\mathrm{g}^{-1}$, respectively. Zhang et al. (2010) investigated the TPC during pomegranate leaf growth by solvent extraction using acidified methanol/water (1:1), achieving TPC values ranging from 210 to $240 \mathrm{GAE} \mathrm{mg}$. $\mathrm{g}^{-1}$. Zhang et al. (2011) obtained a similar TPC (289.76 $\pm 1.55 \mathrm{GAE} \mathrm{mg} . \mathrm{g}^{-1}$ d.w.) from maceration using $70 \%$ ethanol. Garima and Akoh (2009) studied the phenolic content of the leaves of six pomegranate cultivars, obtaining lower TPC values (3.44-3.81 GAE mg. $\mathrm{g}^{-1}$ fresh weight) than those obtained in this work.

\subsection{Antioxidant Activity}

In Figure 2-C, a similar profile can be seen in the antioxidant activity isotherms as pressure increases independently of temperature. In general, the antioxidant activity (AA) of the extracts is high, ranging from 40.2 to $60.7 \%$ depending on the extraction conditions. It is important to understand how extraction conditions can influence the antioxidant activity of the extract. The results indicate that the antioxidant activity of the extracts is not strongly influenced by pressure and temperature, except in the region of $20 \mathrm{MPa}$, where the antioxidant activity was significantly lower $(\mathrm{p}<0.05)$. The highest antioxidant activity was achieved at the extremes of the pressure range $(10$ and $30 \mathrm{MPa})$ for both isotherms $\left(54.3-60.7 \%\right.$ and $54.8-59.9 \%$ for $40^{\circ} \mathrm{C}$ and $50^{\circ} \mathrm{C}$, respectively). Similar results were found by Kaneria and Chanda (2012), who used DDPH to determine the antioxidant activity (\%) of extract concentrations of $10 \mu \mathrm{g} . \mathrm{ml}^{-1}$ and obtained the following results, in ascending order: 22.0 (water), 25.6 (ethyl acetate), and 69.2\% (acetone). Tehranifar et al. (2011) also used DDPH and achieved lower results (10.7-22.1\%) than those obtained in this study

\subsection{Cost of Manufacturing (COM)}

According to Table 1, the COM composition presented a significant variation $(\mathrm{p}<0.05)$ with respect to the pressure and temperature conditions evaluated in this study. Likewise, the increase in extraction column capacity affected the COM components, exerting a beneficial or deleterious effect depending on the COM component evaluated. The cost of labor (COL) and fixed cost of investment (FCI) decreased with increasing volumetric capacities, which were more pronounced in FCI than in COL. Otherwise, the increase in the volumetric capacity of the extraction vessels increased the costs of raw materials (CRM) and utilities (CUT). The costs of manufacturing $(\mathrm{COM})$ obtained by SFE simulation under different temperature and pressure conditions using three extraction vessels with volumetric capacities of $0.1,0.4$ and $1.0 \mathrm{~m}^{3}$ are also presented in Table 1 . As can be seen, the scale-up decreases manufacturing costs; that is, the larger industrial capacity used is, the lower the COM. This phenomenon is mainly due to the reduction of the FCI effect with scale-up. Nevertheless, the manufacturing costs for the SFE of the pomegranate leaves were very high, mainly due to the low yields of the 
extracts, which make the process economically unfeasible under the operational conditions studied. Although the $\mathrm{COM}$ is a direct function of temperature and pressure, mainly due to energy costs, the extraction yield was the factor that exhibited the most influence, causing a significant decrease in COM. Similar observations were reported in previous studies (Albuquerque \& Meireles, 2012; Prado et al., 2010; Prado et al., 2012).

Table 1. Economic evaluation of SFE of pomegranate leaves at different temperature and pressure conditions using two extraction columns at $0.1,0.4$ and $1.0 \mathrm{~m}^{3}$ of capacity

\begin{tabular}{|c|c|c|c|c|c|c|c|c|c|}
\hline \multirow{3}{*}{$\begin{array}{l}\text { Economic } \\
\text { Parameter }\end{array}$} & \multirow{3}{*}{$\begin{array}{c}\text { Extraction } \\
\text { Vessel } \\
\text { Capacity } \\
\left(\mathrm{m}^{3}\right)\end{array}$} & \multicolumn{8}{|c|}{ Operational extraction condition } \\
\hline & & \multicolumn{4}{|c|}{$40^{\circ} \mathrm{C}$} & \multicolumn{4}{|c|}{$50^{\circ} \mathrm{C}$} \\
\hline & & $10 \mathrm{MPa}$ & $15 \mathrm{MPa}$ & $20 \mathrm{MPa}$ & $30 \mathrm{MPa}$ & $10 \mathrm{MPa}$ & $15 \mathrm{MPa}$ & $20 \mathrm{MPa}$ & $30 \mathrm{MPa}$ \\
\hline \multirow{3}{*}{$\begin{array}{c}\mathrm{COM} \\
(\mathrm{US} \$ / \mathrm{kg})\end{array}$} & 0.1 & $461.56^{\mathrm{aB}}$ & $275.75^{\mathrm{aC}}$ & $194.89^{\mathrm{aD}}$ & $182.43^{\mathrm{aD}}$ & $1460.86^{\mathrm{aA}}$ & $246.21^{\mathrm{aC}}$ & $185.59^{\mathrm{aD}}$ & $153.17^{\mathrm{aD}}$ \\
\hline & 0.4 & $354.40^{\mathrm{bB}}$ & $213.20^{\mathrm{bC}}$ & $150.38^{\mathrm{bD}}$ & $141.34^{\mathrm{bD}}$ & $1150.92^{\mathrm{bA}}$ & $192.20^{\mathrm{bC}}$ & $145.07^{\mathrm{bD}}$ & $119.87^{\mathrm{bE}}$ \\
\hline & 1.0 & $337.16^{\mathrm{bB}}$ & $202.46^{\mathrm{bC}}$ & $143.03^{\mathrm{bD}}$ & $134.38^{\mathrm{bD}}$ & $1102.22^{\mathrm{cA}}$ & $183.33^{\mathrm{cC}}$ & $138.38^{\mathrm{bD}}$ & $114.36^{\mathrm{bE}}$ \\
\hline \multirow{3}{*}{ FCI (\%) } & 0.1 & $56.64^{\mathrm{aA}}$ & $56.51^{\mathrm{aA}}$ & $56.43^{\mathrm{aB}}$ & $56.30^{\mathrm{aC}}$ & $55.50^{\mathrm{aD}}$ & $55.32^{\mathrm{aE}}$ & $55.24^{\mathrm{aE}}$ & $55.10^{\mathrm{aF}}$ \\
\hline & 0.4 & $28.81^{\mathrm{bA}}$ & $28.67^{\mathrm{bB}}$ & $28.59^{\mathrm{bB}}$ & $28.46^{\mathrm{bC}}$ & $27.65^{\mathrm{bD}}$ & $27.47^{\mathrm{bE}}$ & $27.39^{\mathrm{bE}}$ & $27.26^{\mathrm{bF}}$ \\
\hline & 1.0 & $14.53^{\mathrm{cA}}$ & $14.44^{\mathrm{cB}}$ & $14.39^{\mathrm{cC}}$ & $14.31^{\mathrm{cC}}$ & $13.80^{\mathrm{cD}}$ & $13.69^{\mathrm{cE}}$ & $13.64^{\mathrm{cE}}$ & $13.56^{\mathrm{cF}}$ \\
\hline \multirow{3}{*}{ CUT $(\%)$} & 0.1 & $26.83^{\mathrm{cE}}$ & $26.91^{\mathrm{cD}}$ & $26.91^{\mathrm{cD}}$ & $26.89^{\mathrm{cD}}$ & $28.30^{\mathrm{cC}}$ & $28.44^{\mathrm{cB}}$ & $28.46^{\mathrm{cA}}$ & $28.44^{\mathrm{cB}}$ \\
\hline & 0.4 & $54.57^{\mathrm{bE}}$ & $54.60^{\mathrm{bE}}$ & $54.54^{\mathrm{bE}}$ & $54.37^{\mathrm{bF}}$ & $56.40^{\mathrm{bC}}$ & $56.49^{\mathrm{bA}}$ & $56.44^{\mathrm{bB}}$ & $56.28^{\mathrm{bD}}$ \\
\hline & 1.0 & $68.81^{\mathrm{aD}}$ & $68.76^{\mathrm{aE}}$ & $68.63^{\mathrm{aF}}$ & $68.33^{\mathrm{aG}}$ & $70.38^{\mathrm{aA}}$ & $70.38^{\mathrm{aA}}$ & $70.26^{\mathrm{aB}}$ & $69.98^{\mathrm{aC}}$ \\
\hline \multirow{3}{*}{ CRM (\%) } & 0.1 & $5.38^{\mathrm{cD}}$ & $5.46^{\mathrm{cC}}$ & $5.55^{\mathrm{cB}}$ & $5.72^{\mathrm{cA}}$ & $5.27^{\mathrm{cE}}$ & $5.35^{\mathrm{cD}}$ & $5.43^{\mathrm{cC}}$ & $5.60^{\mathrm{cB}}$ \\
\hline & 0.4 & $10.94^{\mathrm{bD}}$ & $11.09^{\mathrm{bC}}$ & $11.25^{\mathrm{bB}}$ & $11.57^{\mathrm{bA}}$ & $10.50^{\mathrm{bG}}$ & $10.63^{\mathrm{bF}}$ & $10.78^{\mathrm{bE}}$ & $11.09^{\mathrm{bC}}$ \\
\hline & 1.0 & $13.8^{\mathrm{aD}}$ & $13.96^{\mathrm{aC}}$ & $14.16^{\mathrm{aB}}$ & $14.55^{\mathrm{aA}}$ & $13.11^{\mathrm{aG}}$ & $13.24^{\mathrm{aF}}$ & $13.41^{\mathrm{aE}}$ & $13.79^{\mathrm{aD}}$ \\
\hline \multirow{3}{*}{ COL $(\%)$} & 0.1 & $11.15^{\mathrm{aA}}$ & $11.12^{\mathrm{aB}}$ & $11.11^{\mathrm{aB}}$ & $11.09^{\mathrm{aB}}$ & $10.92^{\mathrm{aC}}$ & $10.89^{\mathrm{aC}}$ & $10.87^{\mathrm{aC}}$ & $10.84^{\mathrm{aD}}$ \\
\hline & 0.4 & $5.67^{\mathrm{bA}}$ & $5.65^{\mathrm{bA}}$ & $5.62^{\mathrm{bB}}$ & $5.6^{\mathrm{bB}}$ & $5.44^{\mathrm{bC}}$ & $5.41^{\mathrm{bD}}$ & $5.39^{\mathrm{bD}}$ & $5.37^{\mathrm{bD}}$ \\
\hline & 1.0 & $2.86^{\mathrm{cA}}$ & $2.84^{\mathrm{cA}}$ & $2.83^{\mathrm{cA}}$ & $2.82^{\mathrm{cA}}$ & $2.71^{\mathrm{cB}}$ & $2.69^{\mathrm{cC}}$ & $2.68^{\mathrm{cC}}$ & $2.67^{\mathrm{cC}}$ \\
\hline
\end{tabular}

${ }^{\mathrm{a}-\mathrm{c}}$ Values followed by different letters at the same column for each economic parameter indicate significant differences between the extraction vessel capacity, according to Tukey Test $(p<0.05)$. ${ }^{\text {A-G }}$ Values followed by different letters at the same row for each economic parameter indicate significant differences between the extraction conditionon the same extraction vessel capacity, according to Tukey test $(\mathrm{p}<0.05)$.

\subsection{Multivariate Analysis}

Principal component analysis (PCA) is a variable reduction procedure used to shrink the number of artificial variables to a set of principal components (PCs), which will account for most of the variance in the observed variables. If variables are highly related, they can be combined into a component that accounts for the most variance in the sample (observations). The second component explains the second highest amount of variance and will not be correlated to the first component (Lattin, Carroll, \& Green, 2003). The absolute value of the loadings is an indicator of the participation of the analyzed parameters in the PCs. The factor loadings are represented as vectors (positions) in the space created by the axes of the biplot graphic (Lattin et al., 2003). According to the PCA results (Table 2), four dimensions were necessary for complete explanation of the data variability. The first two principal components, PC1 (72.87\%) and PC2 (16.28\%), together explained approximately $89.15 \%$ of the total data variability. In decreasing order, PC1 presents a high correlation with EY and COMs, whilst PC2 is strongly related to the variables TPC and AA. 
Table 2. Loadings, eigenvalues and percentage of cumulative variance for the first four varimax rotated principal components (PCs)

\begin{tabular}{lcccc}
\hline Parameters & PC1 & PC2 & PC3 & PC4 \\
\hline EY & -0.891 & -0.154 & -0.125 & 0.408 \\
TPC & -0.598 & 0.668 & 0.438 & 0.060 \\
$\mathrm{AA}$ & 0.570 & 0.707 & -0.415 & 0.058 \\
$\mathrm{COM}^{0.1}$ & 0.983 & -0.047 & 0.130 & 0.119 \\
$\mathrm{COM}^{0.4}$ & 0.982 & -0.048 & 0.132 & 0.126 \\
$\mathrm{COM}^{1.0}$ & 0.982 & -0.048 & 0.132 & 0.128 \\
Eigenvalue & 4.372 & 0.977 & 0.431 & 0.220 \\
\% Variance & 72.871 & 16.279 & 7.186 & 3.664 \\
Cumulative variance\% & 72.871 & 89.150 & 96.336 & 100.000 \\
\hline
\end{tabular}

Figure 3 shows the PCA plot of the loadings (variables) and scores (observations) of the supercritical extracts expressed as function of the temperature $\left({ }^{\circ} \mathrm{C}\right)$ and pressure (MPa) used in SFE assays. In this figure, variables and observations that are close to each other and in the same geometric plane are interrelated; if the observations are distant from the variables, they are not related or even negatively related (Granato, Branco, Faria, \& Cruz, 2011). Thus, supercritical extracts located on the left side of the biplot between attribute vectors indicate higher EY and TPC, while those located on the right side have higher antioxidant activities and manufacturing costs for $0.1,0.4$ and $1.0 \mathrm{~m}^{3}$ extraction column capacities $\left(\mathrm{COM}^{0.1}, \mathrm{COM}^{0.4}\right.$, and $\mathrm{COM}^{1.0}$, respectively). These results can be corroborated by the matrix of the Pearson correlation coefficients (Table 3), which shows that antioxidant activity is inversely related to extraction yield $\left(\mathrm{r}^{2}=-0.541\right)$ and is weakly affected by phenolic content $\left(\mathrm{r}^{2}=\right.$ -0.047). This phenomenon indicates that antioxidant activity is probably affected by the coextraction of non-polyphenolic compounds. Synergisms or antagonisms between the different polyphenols (or non-polyphenolic compounds) may be occurring, affecting the overall antioxidant activity (Gramza \& Korczak, 2005; Pinelo, Manzocco, Nuñez, \& Nicoli, 2004; Seeram et al., 2005). The extraction yield has a direct intermediate correlation with phenolic content $\left(\mathrm{r}^{2}=0.400\right)$ and is negatively related with $\operatorname{COM}^{0.1}\left(\mathrm{r}^{2}=-0.837\right)$, $\mathrm{COM}^{0.4}(-0.833)$, and $\mathrm{COM}^{1.0}(-0.832)$, corroborating the theory that lower extraction yields translate into higher manufacturing costs.

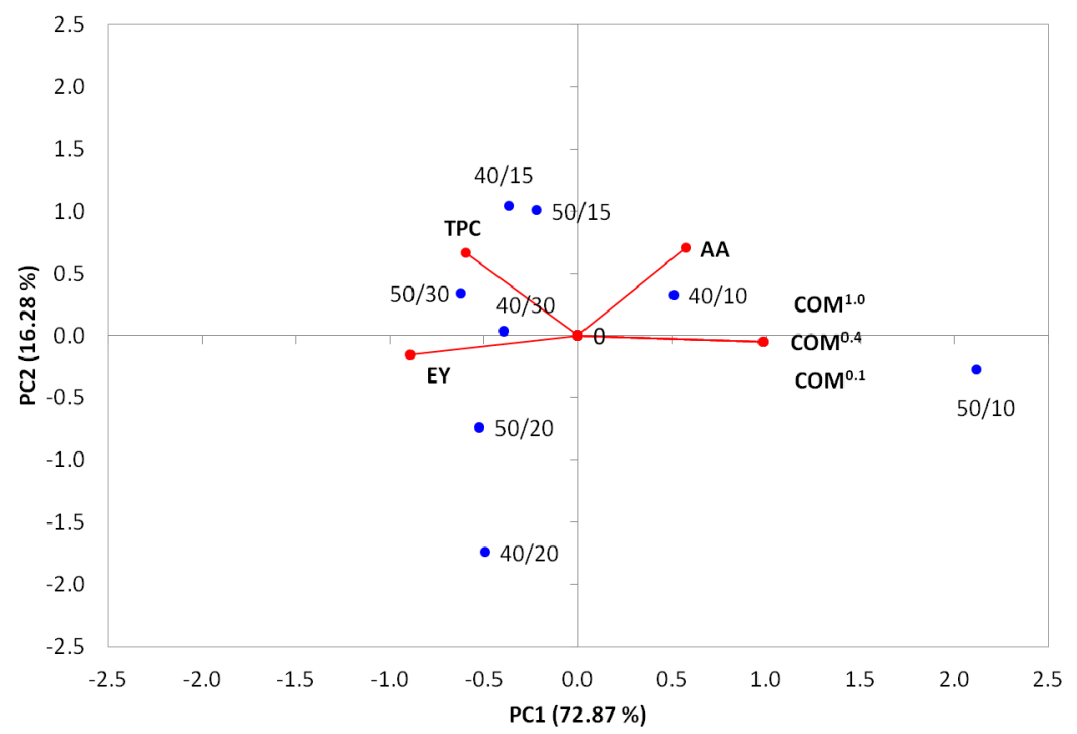

Figure 3. PCA plot of the relationship between extraction conditions (temperature ${ }^{\circ} \mathrm{C} / \mathrm{pressureMPa}$ ) variables and the attributes: extraction yield (EY), total phenolic content (TPC), antioxidant activity (AA), and cost of manufacturing for $0.1\left(\mathrm{COM}^{0.1}\right), 0.4\left(\mathrm{COM}^{0.4}\right)$ and $1.0\left(\mathrm{COM}^{1.0}\right) \mathrm{m}^{3}$ of extraction column capacity 
Table 3.Correlation matrix of Pearson

\begin{tabular}{lccccc}
\hline & EY & TPC & AA & COM $^{0.1}$ & COM $^{0.4}$ \\
\hline TPC & 0.400 & & & & \\
AA & -0.541 & -0.047 & & & \\
$\mathrm{COM}^{0.1}$ & -0.837 & -0.556 & 0.481 & & \\
$\mathrm{COM}^{0.4}$ & -0.833 & -0.554 & 0.478 & 1.000 & \\
$\mathrm{COM}^{1.0}$ & -0.832 & -0.554 & 0.478 & 1.000 & 1.000 \\
\hline
\end{tabular}

\subsection{Gas Chromatography-mass Spectrometry Analysis}

To identify the presence of non-polyphenolic compounds in the SFE extracts of pomegranate leaves and to determine their relationship with the observed antioxidant activities of the extracts, a GC-MS analysis of a blend of all of the extracts was performed (Table 3). Relatively high levels of eicosanol (15.45\%), squalene (12.51\%), tocoferol derivatives $(9.78 \%)$ and linoleic acid $(8.52 \%)$ were detected in the samples, indicating that the coextraction of non-polyphenolic components may be affecting the antioxidant activities of the extracts. Several studies have attributed many functional properties to those compounds, which are mainly associated with their high antioxidant activity (Baldioli, Servili, Perretti, \& Montedoro, 1996; Ko, Weng, \& Chiou, 2002).

Squalene is a triterpenic hydrocarbon, a known natural antioxidant commonly used in folk medicine to treat chronic diseases due to its antitumor and anticarcinoma activities (Ko et al., 2002). Because its main sources, shark liver and olive oils, have been extensively studied and explored, others squalene sources should be investigated. Tocopherols and tocotrienols are bioactive phytochemical compounds with high antioxidant activities that play an important role in the food industry as lipid stabilizers and in medicine as suppressors of free radicals that potentially lead to cancer and aging (Tsochatzis, Bladenopoulos, \& Papageorgiou, 2012). The essential polyunsaturated fatty acids (PUFAs) are divided into two classes, $n-3(\omega-3)$ and $n-6(\omega-6)$, and their dietary precursors are $\alpha$-linolenic (ALA) and linoleic acid (LA), respectively. PUFAs are precursors for a wide range of metabolites, such as the eicosanoids, prostaglandins and leukotrienes, that are critical in regulating a variety of biological processes, including skin, bone and liver metabolism (Galli \& Marangoni, 1997; Maggio et al., 2011).

\section{Conclusion}

According to the PCA results, the most effective operational condition for the supercritical $\mathrm{CO}_{2}$ extraction of phenolic compounds from pomegranate leaves was found to be at $50^{\circ} \mathrm{C}$ and $30 \mathrm{MPa}$; a high extraction yield and phenolic content and low COM were obtained under these conditions. The antioxidant activity had a negative correlation with phenolic content and extraction yield, indicating the potential co-extraction of non-polyphenolic compounds. This assumption was corroborated by the GC-MS analysis results that indicated that the antioxidant activity was influenced by high levels of eicosanol $(15.45 \%)$, squalene $(12.51 \%)$ and tocoferol derivatives (9.78\%). Although the supercritical extracts had high phenolic contents, the low extraction yields and high manufacturing costs indicate that the $\mathrm{SC}-\mathrm{CO}_{2}$ extraction of polyphenolics from pomegranate leaves is not economically viable. However, as seen by GC-MS analysis, this method may be used as a pretreatment to purify the plant matrix before the extraction of phenolic compounds. Thus, further studies should investigate the use of a co-solvent in the SFE of polar compounds with the subsequent application of pure $\mathrm{CO}_{2}$ to obtain two different extracts: one rich in non-polar compounds and one with a high content of polyphenols.

\section{Acknowledgments}

The authors acknowledge the financial support from Conselho Nacional de Desenvolvimento Científico e Tecnológico (CNPq) and Coordenação de Aperfeiçoamento de Pessoal de Nível Superior (CAPES). Diego T. Santos would like to thank FAPESP (10/16485-5) for his postdoctoral fellowship.

\section{References}

Adhami, V. M., \& Mukhtar, H. (2006). Polyphenols from green tea and pomegranate for prevention of prostate cancer. Free Radical Research, 40(10), 1095-1104. http://dx.doi.org/10.1080/10715760600796498

Aguilera-Carbo, A. F., Augur, C., Prado-Barragan, L. A., Aguilar, C. N., \& Favela-Torres, E. (2008). Extraction and analysis of ellagic acid from novel complex sources. Chemical Papers, 62(4), 440-444. http://dx.doi.org/10.2478/s11696-008-0042-y 
Albuquerque, C. L. C., \& Meireles, M. A. A. (2012). Defatting of annatto seeds using supercritical carbon dioxide as a pretreatment for the production of bixin: Experimental, modeling and economic evaluation of the process. Journal of Supercritical Fluids. http://dx.doi.org/10.1016/j.supflu.2012.01.004

Al-Muammar, M. N., \& Khan, F. (2012). Obesity: The preventive role of the pomegranate (Punica granatum). Nutrition, 28(6), 595-604. http://dx.doi.org/10.1016/j.nut.2011.11.013

Anoosh, E., Mojtaba, E., \& Fatemeh, S. (2010). Study the effect of juice of two variety of pomegranate on decreasing plasma LDL cholesterol. Procedia - Social and Behavioral Sciences, 2(2), 620-623.

Baldioli, M., Servili, M., Perretti, G., \& Montedoro, G. F. (1996). Antioxidant activity of tocopherols and phenolic compounds of virgin olive oil. JAOCS, Journal of the American Oil Chemists' Society, 73(11), 1589-1593.

Brunner, G. (2005). Supercritical fluids: Technology and application to food processing. Journal of Food Engineering, 67(1-2), 21-33. http://dx.doi.org/10.1016/j.jfoodeng.2004.05.060

Burda, S., \& Oleszek, W. (2001). Antioxidant and antiradical activities of flavonoids. Journal of Agricultural and Food Chemistry, 49(6), 2774-2779. http://dx.doi.org/10.1021/jf001413m

Çam, M., \& Hişil, Y. (2010). Pressurised water extraction of polyphenols from pomegranate peels. Food Chemistry, 123(3), 878-885. http://dx.doi.org/10.1016/j.foodchem.2010.05.011

Casas, L., Mantell, C., Rodríguez, M., Ossa, E. J. M. d. 1., Roldán, A., Ory, I. D., ... Blandino, A. (2010). Extraction of resveratrol from the pomace of Palomino fino grapes by supercritical carbon dioxide. Journal of Food Engineering, 96(2), 304-308. http://dx.doi.org/10.1016/j.jfoodeng.2009.08.002

Das, S., \& Barman, S. (2012). Antidiabetic and antihyperlipidemic effects of ethanolic extract of leaves of Punica granatum in alloxan-induced non-insulin-dependent diabetes mellitus albino rats. Indian Journal of Pharmacology, 44(2), 219-224. http://dx.doi.org/10.4103/0253-7613.93853

Endo, E. H., Garcia Cortez, D. A., Ueda-Nakamura, T., Nakamura, C. V., \& Dias Filho, B. P. (2010). Potent antifungal activity of extracts and pure compound isolated from pomegranate peels and synergism with fluconazole against Candida albicans. Research in Microbiology, 161(7), 534-540. http://dx.doi.org/10.1016/j.resmic.2010.05.002

Galli, C., \& Marangoni, F. (1997). Recent advances in the biology of n-6 fatty acids. Nutrition, 13(11-12), 978-985. http://dx.doi.org/10.1016/S0899-9007(97)00341-9

Garima, P., \& Akoh, C. C. (2009). Antioxidant capacity and lipid characterization of six georgia-grown pomegranate cultivars. Journal of Agricultural and Food Chemistry, 57(20), 9427-9436. http://dx.doi.org/10.1021/jf901880p

Gramza, A., \& Korczak, J. (2005). Tea constituents (Camellia sinensis L.) as antioxidants in lipid systems. Trends in Food Science and Technology, 16(8), 351-358. http://dx.doi.org/10.1016/j.tifs.2005.02.004

Granato, D., Branco, G. F., Faria, J. D. A. F., \& Cruz, A. G. (2011). Characterization of Brazilian lager and brown ale beers based on color, phenolic compounds, and antioxidant activity using chemometrics. Journal of the Science of Food and Agriculture, 91(3), 563-571. http://dx.doi.org/10.1002/jsfa.4222

Herrero, M., Cifuentes, A., \& Ibañez, E. (2006). Sub- and supercritical fluid extraction of functional ingredients from different natural sources: Plants, food-by-products, algae and microalgae - A review. Food Chemistry, 98(1), 136-148. http://dx.doi.org/10.1016/j.foodchem.2005.05.058

Herrero, M., Mendiola, J. A., Cifuentes, A., \& Ibáñez, E. (2010). Supercritical fluid extraction: Recent advances and applications. Journal of Chromatography A, 1217(16), 2495-2511. http://dx.doi.org/10.1016/j.chroma.2009.12.019

Huang, T. H. W., Peng, G., Kota, B. P., Li, G. Q., Yamahara, J., Roufogalis, B. D., \& Li, Y. (2005). Anti-diabetic action of Punica granatum flower extract: Activation of PPAR- $\gamma$ and identification of an active

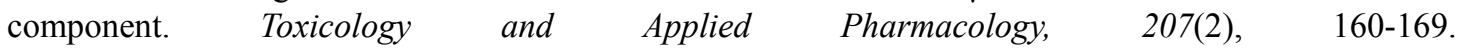
http://dx.doi.org/10.1016/j.taap.2004.12.009

Ignat, I., Volf, I., \& Popa, V. I. (2011). A critical review of methods for characterisation of polyphenolic compounds in fruits and vegetables. Food Chemistry, 126(4), 1821-1835. http://dx.doi.org/10.1016/j.foodchem.2010.12.026

Jacobs, M. B. (1973). The Chemical Analysis of Foods and Food Products (3rd ed.). New York: Publishing Co. 
Inc.

Johann, S., Silva, D. L., Martins, C. V. B., Zani, C. L., Pizzolatti, M. G., \& Resende, M. A. (2008). Inhibitory effect of extracts from Brazilian medicinal plants on the adhesion of Candida albicans to buccal epithelial cells. World Journal of Microbiology and Biotechnology, 24(11), 2459-2464. http://dx.doi.org/10.1007/s11274-008-9768-5

Johanningsmeier, S. D., \& Harris, G. K. (2011). Pomegranate as a functional food and nutraceutical source. Annual Review of Food Science and Technology, 2, 181-201. $\mathrm{http}: / / \mathrm{dx}$.doi.org/10.1146/annurev-food-030810-153709

Kaneria, M. J., \& Chanda, S. V. (2012). The Effect of Sequential Fractionation Technique on the Various Efficacies of Pomegranate (Punica granatum L.). Food Analytical Methods, 1-12.

Kaneria, M. J., Bapodara, M. B., \& Chanda, S. V. (2012). Effect of Extraction Techniques and Solvents on Antioxidant Activity of Pomegranate (Punica granatum L.) Leaf and Stem. Food Analytical Methods, 5(3), 396-404. http://dx.doi.org/10.1007/s12161-011-9257-6

Kaur, G., Jabbar, Z., Athar, M., \& Alam, M. S. (2006). Punica granatum (pomegranate) flower extract possesses potent antioxidant activity and abrogates Fe-NTA induced hepatotoxicity in mice. Food and Chemical Toxicology, 44(7), 984-993. http://dx.doi.org/10.1016/j.fct.2005.12.001

Khan, N., \& Mukhtar, H. (2007). Pomegranate fruit as a lung cancer chemopreventive agent. Drugs of the Future, 32(6), 549-554. http://dx.doi.org/10.1358/dof.2007.032.06.1097137

Khan, N., Afaq, F., Kweon, M. H., Kim, K., \& Mukhtar, H. (2007). Oral consumption of pomegranate fruit extract inhibits growth and progression of primary lung tumors in mice. Cancer Research, 67(7), 3475-3482. http://dx.doi.org/10.1158/0008-5472.CAN-06-3941

Ko, T. F., Weng, Y. M., \& Chiou, R. Y. Y. (2002). Squalene content and antioxidant activity of Terminalia catappa leaves and seeds. Journal of Agricultural and Food Chemistry, 50(19), 5343-5348. http://dx.doi.org/10.1021/jf0203500

Lansky, E. P., \& Newman, R. A. (2007). Punica granatum (pomegranate) and its potential for prevention and treatment of inflammation and cancer. Journal of Ethnopharmacology, 109(2), 177-206. http://dx.doi.org/10.1016/j.jep.2006.09.006

Lattin, J., Carroll, J. D., \& Green, P. E. (2003). Analyzing Multivariate Data. Toronto: Thomson Learning, Inc.

Lee, C. J., Chen, L. G., Liang, W. L., \& Wang, C. C. (2010). Anti-inflammatory effects of Punica granatum Linne in vitro and in vivo. Food Chemistry, 118(2), 315-322. http://dx.doi.org/10.1016/j.foodchem.2009.04.123

Lei, F., Zhang, X. N., Wang, W., Xing, D. M., Xie, W. D., Su, H., \& Du, L. J. (2007). Evidence of anti-obesity effects of the pomegranate leaf extract in high-fat diet induced obese mice. International Journal of Obesity, 31(6), 1023-1029. http://dx.doi.org/10.1038/sj.ijo.0803502

Liu, G., Xu, X., Hao, Q., \& Gao, Y. (2009). Supercritical CO2 extraction optimization of pomegranate (Punica granatum L.) seed oil using response surface methodology. LWT - Food Science and Technology, 42(9), 1491-1495.

Maggio, M., Artoni, A., Lauretani, F., Ruggiero, C., Cederholm, T., Cherubini, A., \& Ceda, G. P. (2011). The effect of polyunsaturated fatty acids on bone health. Reviews in Clinical Gerontology, 21(3), 219-232. http://dx.doi.org/10.1017/S0959259810000456

Marco, G. J. (1968). A rapid method for evaluation of antioxidants. Journal of the American Oil Chemists' Society, 45(9), 594-598.

Mchugh, M. A., \& Krukonis, V. J. (1994). Supercritical fluid extraction: principles and practice (2nd ed.). Boston: Butterworth-Heinemann.

Miller, H. (1971). A simplified method for the evaluation of antioxidants. Journal of the American Oil Chemists' Society, 48(2), 91-91.

Nair, R. R., \& Chanda, S. V. (2005). Punica granatum: A potential source as antibacterial drug. Asian Journal of Microbiology, Biotechnology and Environmental Sciences, 7(4), 625-628.

Pereira, C. G., \& Meireles, M. A. A. (2010). Supercritical fluid extraction of bioactive compounds: Fundamentals, applications and economic perspectives. Food and Bioprocess Technology, 3(3), 340-372. 
http://dx.doi.org/10.1007/s11947-009-0263-2

Pinelo, M., Manzocco, L., Nuñez, M. J., \& Nicoli, M. C. (2004). Interaction among Phenols in Food Fortification: Negative Synergism on Antioxidant Capacity. Journal of Agricultural and Food Chemistry, 52(5), 1177-1180. http://dx.doi.org/10.1021/jf0350515

Prado, J. M., Assis, A. R., Maróstica-Júnior, M. R., \& Meireles, M. A. A. (2010). Manufacturing cost of supercritical-extracted oils and carotenoids from amazonian plants. Journal of Food Process Engineering, 33(2), 348-369. http://dx.doi.org/10.1111/j.1745-4530.2008.00279.x

Prado, J. M., Dalmolin, I., Carareto, N. D. D., Basso, R. C., Meirelles, A. J. A., Oliveira, J. V., ... Meireles, M. A. A. (2012). Supercritical fluid extraction of grape seed: Process scale-up, extract chemical composition and economic evaluation. Journal of Food Engineering, 109, 249-257. http://dx.doi.org/10.1016/j.jfoodeng.2011.10.007

Rababah, T. M., Banat, F., Rababah, A., Ereifej, K., \& Yang, W. (2010). Optimization of extraction conditions of total phenolics, antioxidant activities, and anthocyanin of oregano, thyme, terebinth, and pomegranate. Journal of Food Science, 75(7), C626-C632. http://dx.doi.org/10.1111/j.1750-3841.2010.01756.x

Reddy, M. K., Gupta, S. K., Jacob, M. R., Khan, S. I., \& Ferreira, D. (2007). Antioxidant, antimalarial and antimicrobial activities of tannin-rich fractions, ellagitannins and phenolic acids from Punica granatum L. Planta Medica, 73(5), 461-467. http://dx.doi.org/10.1055/s-2007-967167

Rios, J. J., \& Gutiérrez-Rosales, F. (2010). Comparison of methods extracting phenolic compounds from lyophilised and fresh olive pulp. LWT - Food Science and Technology, 43(8), 1285-1288.

Rosa, P. T. V., \& Meireles, M. A. A. (2005). Rapid estimation of the manufacturing cost of extracts obtained by supercritical fluid extraction. Journal of Food Engineering, 67(1-2), 235-240. http://dx.doi.org/10.1016/j.jfoodeng.2004.05.064

Rostagno, M. A., Araújo, J. M. A., \& Sandi, D. (2002). Supercritical fluid extraction of isoflavones from soybean flour. Food Chemistry, 78(1), 111-117. http://dx.doi.org/10.1016/S0308-8146(02)00106-1

Santos, D. T., Veggi, P. C., \& Meireles, M. A. A. (2010). Extraction of antioxidant compounds from Jabuticaba (Myrciaria cauliflora) skins: Yield, composition and economical evaluation. Journal of Food Engineering, 101(1), 23-31. http://dx.doi.org/10.1016/j.jfoodeng.2010.06.005

Seeram, N. P., Adams, L. S., Henning, S. M., Niu, Y., Zhang, Y., Nair, M. G., \& Heber, D. (2005). In vitro antiproliferative, apoptotic and antioxidant activities of punicalagin, ellagic acid and a total pomegranate tannin extract are enhanced in combination with other polyphenols as found in pomegranate juice. Journal of Nutritional Biochemistry, 16(6), 360-367. http://dx.doi.org/10.1016/j.jnutbio.2005.01.006

Sharma, R., \& Arya, V. (2011). A review on fruits having anti-diabetic potential. Journal of Chemical and Pharmaceutical Research, 3(2), 204-212.

Singleton, V. L., Orthofer, R., \& Lamuela-Raventós, R. M. (1998). Analysis of total phenols and other oxidation substrates and antioxidants by means of folin-ciocalteu reagent. Methods in Enzymology, 299, 152-178. http://dx.doi.org/10.1016/S0076-6879(99)99017-1

Souza, S. S., Cruz, A. G., Walter, E. H. M., Faria, J. A. F., Celeghini, R. M. S., Ferreira, M. M. C., ... Sant'Ana, A. D. S. (2011). Monitoring the authenticity of Brazilian UHT milk: A chemometric approach. Food Chemistry, 124(2), 692-695. http://dx.doi.org/10.1016/j.foodchem.2010.06.074

$\mathrm{Su}, \mathrm{X}$., Sangster, M. Y., \& D'Souza, D. H. (2010). In vitro effects of pomegranate juice and pomegranate polyphenols on foodborne viral surrogates. Foodborne Pathogens and Disease, 7(12), 1473-1479. http://dx.doi.org/10.1089/fpd.2010.0583

Su, X., Sangster, M. Y., \& D'Souza, D. H. (2011). Time-dependent effects of pomegranate juice and pomegranate polyphenols on foodborne viral reduction. Foodborne Pathogens and Disease, 8(11), 1177-1183. http://dx.doi.org/10.1089/fpd.2011.0873

Taylor, L. T. (1996). Supercritical fluid extraction. New York: John Wiley \& Sons Inc.

Tehranifar, A., Selahvarzi, Y., Kharrazi, M., \& Bakhsh, V. J. (2011). High potential of agro-industrial by-products of pomegranate (Punica granatum L.) as the powerful antifungal and antioxidant substances. Industrial Crops and Products, 34(3), 1523-1527. http://dx.doi.org/10.1016/j.indcrop.2011.05.007 
Toklu, H. Z., Dumlu, M. U., Sehirli, Ö., Ercan, F., Gedik, N., Gökmen, V., \& Sener, G. (2007). Pomegranate peel extract prevents liver fibrosis in biliary-obstructed rats. Journal of Pharmacy and Pharmacology, 59(9), 1287-1295. http://dx.doi.org/10.1211/jpp.59.9.0014

Toklu, H. Z., Şehirli, O., Özyurt, H., Mayadağli, A. A., Ekşioğlu-Demiralp, E., Çetinel, S., ... Şener, G. (2009). Punica granatum peel extract protects against ionizing radiation - Induced enteritis and leukocyte apoptosis in rats. Journal of Radiation Research, 50(4), 345-353. http://dx.doi.org/10.1269/jrr.08126

Tsochatzis, E. D., Bladenopoulos, K., \& Papageorgiou, M. (2012). Determination of tocopherol and tocotrienol content of Greek barley varieties under conventional and organic cultivation techniques using validated reverse phase high-performance liquid chromatography method. Journal of the Science of Food and Agriculture, 92(8), 1732-1739. http://dx.doi.org/10.1002/jsfa.5539

Turton, R., Bailie, R. C., Whiting, W. B., \& Shaeiwitz, J. A. (2003). Analysis, Synthesis, and Design of Chemical Processes (2nd ed.). New Jersey: Prentice Hall.

Viuda-Martos, M., Fernández-Lóaez, J., \& Pérez-álvarez, J. A. (2010). Pomegranate and its Many Functional Components as Related to Human Health: A Review. Comprehensive Reviews in Food Science and Food Safety, 9(6), 635-654. http://dx.doi.org/10.1111/j.1541-4337.2010.00131.x

Zhang, L., Gao, Y., Zhang, Y., Liu, J., \& Yu, J. (2010). Changes in bioactive compounds and antioxidant activities in pomegranate leaves. Scientia Horticulturae, 123(4), 543-546. http://dx.doi.org/10.1016/j.scienta.2009.11.008

Zhang, L., Yang, X., Zhang, Y., Wang, L., \& Zhang, R. (2011). In vitro antioxidant properties of different parts of pomegranate flowers. Food and Bioproducts Processing, 89(3), 234-240. http://dx.doi.org/10.1016/j.fbp.2010.04.007 